\title{
HISTORIOGRAFIE V DIALOGU O INTERPRETACI POZDNÍHO SOCIALISMU
}

Za text Mateje Cíbika jsem upřímně rád. Po několika vlnách pobouřeného odmítnutí „revizionismu“ v českém dějepisectví státního socialismu se jedná konečně o seriózní kritickou reflexi perspektivy jednoho z historiků, kteří se v posledních letech vymezili proti psaní dějin československého komunismu jakožto dějin útlaku. Mojí intencí i proto není tváří v tvář Cíbikově kritice „,bránit“ pojetí Michala Pullmanna, jež ostatně není totožné s mým vlastním přístupem. Za smysluplné považuji v prvním kroku své argumentace naopak (1) vyzdvihnout sdílené předpoklady Cíbikova, Pullmannova i mého vlastního pohledu na téma našeho dialogu. Vzhledem k povaze Cíbikovy argumentace a především interdisciplinárnímu charakteru polemiky se mi však jeví účelné pro čtenáře Reflexe Pullmannův přístup kontextualizovat a nahlédnout ještě z jiných perspektiv než z té, kterou nabízí Matej Cíbik. V druhém kroku bych proto (2) rád poukázal na myšlenkové inspirace kulturně a sociálně historických přístupů $\mathrm{k}$ dějinám moderních diktatur, $\mathrm{z}$ nichž vyrůstá pojetí Michala Pullmanna i některých dalších českých historiček a historiků, mezi něž se počítám. V souvislosti s těmito východisky se (3) následně vrátím k některým klíčovým pojmům, jako jsou legitimita a konsensus, $\mathrm{k}$ problematice zacházení s jazykem a obecněji povaze ideologie, přičemž bude důležité poukázat i na odlišnou práci s těmito pojmy v rámci našich oborů, filosofie a historiografie (a zastavit se tak u problematiky historizace nedávné minulosti). Konečně (4) se pokusím zamiŕit k tématu, které považuji v celém sporu o naši nedávnou minulost za klíčové a jež je zároveň nejednoduché reflektovat tak, aby nevedlo $\mathrm{k}$ banalizaci či politizaci problému: budu se zabývat souvislostí mezi přijetím či kritickou reflexí hodnotového kánonu, resp. dominantní ideologie soudobého (neo)liberálního kapitalismu a konceptualizací státního socialismu.

\section{Společná východiska}

Matej Cíbik, v souladu s rozššřrenou perspektivou historiografie soudobých dějin, kterou v Česku zastává i Michal Pullmann, přinejmenším ve 
svém pojetí pozdního socialismu implicitně odmítá východiska teoretiků totalitarismu. Ani podle Mateje Cíbika tak nebyl hlavním principem vládnutí v normalizačním dvacetiletí teror, moc neměla monolitickou povahu a společnost nebyla ve všech svých projevech totálně ovládnutá či manipulovaná. Explicitně pak Matej Cíbik odmítá představu všeprostupující ideologie, která byla naopak teoretiky totalitarismu vnímána jako klíčový aspekt odlišující totalitární režimy od klasických diktatur. ${ }^{1}$ V souladu s kritiky teorií totalitarismu Cíbik upozorňuje na skutečnost, že řada aktérů normalizačního Československa (tj. zdaleka ne jen disidenti) v praxi sledovala nonkonformní cíle. Obecně se tak s Michalem Pullmannem i s výsledky mých vlastních výzkumů shoduje na tom, že diktatura, jak ji zažívali například občané pozdně socialistického Československa, nepatři do jakéhosi odděleného světa, v němž platí zcela odlišná logika fungování státu a společnosti, ale může být zkoumána pomocí klasických kategorií, které používáme pro analýzu demokratických i autoritářských režimů.

Jestliže Matej Cíbik ve shodě se stále významnější částí odborné historické literatury neaplikuje na období normalizace představu všeovládající moci a všeprostupující ideologie (popsanou teoretiky totalitarismu v souvislosti s nacismem a stalinismem a i tam spíše ideálně-typicky), neuchyluje se ani k druhému extrému, jenž bývá líčen především některými svědky a pamětníky pozdně socialistické diktatury, ${ }^{2}$ totiž k pojetí ideologie jako všemi zúčastněnými dávno odhalené

1 Klíčovou a dodnes zřejmě nejvlivnější práci zde představuje kniha Puvod totalitarismu německé filosofky H. Arendtové: H. Arendt, Elemente und Ursprünge totaler Herrschaft, Frankfurt a. M. 1955, v českém překladu: H. Arendtová, Puvod totalitarismu, I-III, přel. J. Fraňková et al., Praha 1996. Teorii totalitarismu vyrůstající z oboru politologie přinesla práce Carla Friedricha a Zbigniewa Brzezinskeho: C. Friedrich - Z. Brzezinski, Totalitarian Dictatorship and Autocracy, Boston 1965, tato kniha systematizovala některé teze ze starších Brzezinského prací: Z. Brzezinski, The Permanent Purge. Politics in Soviet Totalitarianism, Cambridge 1956, a týž, Ideology and Power in Soviet Politics, New York 1962.

2 Zde vycházím např́klad z rozhovorů s pamětníky normalizační éry z akademického prostředí, jež jsme realizovali v rámci výzkumu dějin KSČ na FF UK v období normalizace. Jeho hlavní výstup představuje monografie J. Jareš - M. Spurný K. Volná a kol., Náměstí Krasnoarmějcu 2. Učitelé a studenti Filozofické fakulty UK $v$ období normalizace, Praha 2012. Podobné akcenty bychom ovšem našli i ve vzpomínkách a rozhovorech zahrnutých v mnoha jiných publikacích (viz např. M. Vaněk, Obyčejní lidé-?! Pohled do života tzv. mlčící většiny. Životopisná vyprávění příslušníků dělnických profesí a inteligence, Praha 2009) nebo umístěných v databázi organizace Pamět' národa (https://www.pametnaroda.cz/cs/archive). Pojetí, podle něhož bylo užívání ideologického jazyka pouze předstíráním a přetvářkou, tj. čímsi vnějším, 
přetvářky, tj. jako lhaní, jemuž nikdo nevěřil a k němuž se lidé uchylovali pouze z kariérismu a ve snaze vyhnout se problémům. Matej Cíbik, opět ve shodě s širokým proudem kulturněhistorických analýz moderních diktatur, do nějž lze zařadit i Pullmannovy studie, uznává, že „hodnotit každý ne-plně-autentický projev nebo čin jako ,život ve lži ‘ by prozrazovalo nepochopení základních mechanismů mezilidské interakce“. 3 V jakýchkoli podmínkách, komunistické diktatury či liberální demokracie, je totiž jedinec aktérem různých jazykových her a v některých prrípadech ze strategických či jiných důvodů používá ustálené floskule nebo předstírá souhlas, aby se tak vyhnul konfliktům či jiným nepř́ijemným důsledkům nebo aby pro sebe či pro určitý okruh lidí něco vydobyl. Odlišná mluva v různých prostředích (doma, na pracovišti...), která bývá často uváděna jako symptom normalizační přetváŕky a důsledek setrvalého strachu lidí oloupených o svobodu slova, i v dnešní době podle Cíbika (ve shodě s Pullmannem), „často odráží mocenské poměry, očekávání nastavené ,seshora‘ a hodnoty, se kterými se ne vždy musíme plně ztotožňovat". 4

Dialog se tedy odehrává v rámci těchto společně sdílených východisek, ovšem v dalších podstatných otázkách se Matej Cíbik s pojetím Michala Pullmanna rozchází. To bezpochyby platí pro vymezení legitimity (a posouzení, nakolik se jedná o kategorii vlastní normalizačnímu politickému uspořádání), povahu normalizačního konsensu (resp. oprávněnost o konsensu vůbec hovořit) i příčiny stagnace a rozkladu státního socialismu v druhé polovině osmdesátých let. Klíčovým svorníkem Cíbikova postoje se zdá být jeho přesvědčení, že politické „režimy“ lze z hlediska vztahu moci a společnosti, svobody jednání občanů, získávání politické podpory či způsobů řešení problémů kategoricky rozdělit na ty, jež reprezentují vůli svých občanů, a na ostatní, mezi něž patří i režim normalizační, jež ji nereprezentují, udržují si svoji mocenskou strukturu jinak než prostřednictvím demokratických procedur, a $v$ jejichž př́ípadě se tudíž nedá mluvit ani o legitimitě, ani konsensu. V obecné rovině tak Cíbikova kategorizace a jeho pohled na pozdní fázi socialistické diktatury připomínají koncepci posttotalitarismu, jak ji v polovině devadesátých let z pozic komparativní politologie představili Juan Linz a Al-

co si aktéŕi z utilitárních důvodů nasazují jako masku, se opírá také o paradigmatické dobové texty, jak M. Cíbik ukazuje na prríkladu Havlovy Moci bezmocných.

3 M. Cíbik, Michal Pullmann a filosofické aspekty sporu o charakter normaliza$c e$, str. $185 \mathrm{v}$ tomto čísle časopisu.

4 Tamt. 
fred Stepan. ${ }^{5}$ Podle těchto autorů, vycházejících z Linzovy reflektovaně totalitaristické perspektivy, ${ }^{6}$ sice v ,posttotalitárních“ režimech zůstává monistické (nikoli nutně monolitické) centrum, z nějž vychází veškerá moc v úzce chápané politické oblasti, avšak objevuje se větší vnitřní ekonomický, sociální a institucionální pluralismus. Ideologie podle těchto autorů sice zůstává př́ítomným faktorem, ale je již vyprázdněná, a to především ve své utopické složce. Režim se už nevyznačuje širokou a autentickou mobilizací. Ve vládnoucí straně a vůbec na významných rrídících pozicích převažují technokraté a kariéristé. Společnost se více stahuje do soukromí a privatizace společenských hodnot se stává akceptovaným faktem. ${ }^{7}$

Než se pustím do bližšího průzkumu některých aspektů Cíbikovy konceptualizace normalizačního uspořádání (a kritiky některých jeho argumentů, převážně těch historických), musím se zastavit u jím rekonstruované a částečně odmítnuté perspektivy Michala Pullmanna. Ta je totiž v Cíbikově studii podána jako svérázná. Z mého pohledu naopak Pullmannovo pojetí reprezentuje (možná jen o něco explicitněji a místy polemičtěji) vcelku široký proud historiografie soudobých dějin a vyrůstá z celé řady významných výzkumných projektů, publikací a odborných debat několika desetiletí rozvoje sociálních a kulturních dějin moderních diktatur - především v prostředí americké a německé historiografie.

\section{Pullmann ve vzduchoprázdnu}

Cíbik ve své rozsáhlé studii zmiňuje krom Pullmannova Konce experimentu a sborníku textů Co byla normalizace?, který Pullmann vydal společně s Pavlem Kolářem, pouze jedinou další historickou práci (knihu Zelinár a jeho televize od americké historičky Pauliny Bren), okrajově pak ještě uvádí českého historika Milana Otáhala. Nejen téměř úplná absence zahraničních a domácích výzkumů i diskusí (Pullmannovy výroky jsou zasazeny do kontextu filosofické literatury, který je vůči nim externí, nikoli ale do diskusí historiografických), ale i výrazové prostřed-

5 J. Linz - A. Stepan, Problems of Democratic Transition and Consolidation. Southern Europe, South America, and Post-Communist Europe, Baltimore 1996.

6 Souhrnně viz J. Linz, Totalitarian and Authoritarian Regimes, Boulder 2000.

7 Více k tomu viz R. Buben - M. Pullmann - M. Spurný - J. Růžička, Diktatura a autoritářské režimy, in: L. Storchová a kol., Koncepty a dějiny. Proměny pojmů v současné historické vědě, Praha 2014, str. 281-307, zde str. 285-286. 
ky, jimiž autor Pullmannovy postoje představuje, navozují dojem, že tu máme co do činění s osamělým a hodně vyhroceným pojetím posledního dvacetiletí státního socialismu v Československu: Pullmann podle Cíbika „zkrátka věří, že režim vládnoucí v Československu v sedmdesátých a osmdesátých letech (s výjimkou jejich úplného závěru) představoval ... uspořádání, jež do velké míry reflektovalo charakter a přesvědčení tehdejší společnosti... Pullmann zastává v současné filosofické literatuře výrazně menšinový názor, že i v podmínkách diktatury ... lze mluvit o ,dosahování konsensu‘ a ,legitimitě‘... Pullmann si je jisté vratkosti svých prohlášení o legitimitě komunistické diktatury možná vědom, a proto se v tomto bodě zaštit'uje autoritou Maxe Webera“ atd. ${ }^{8}$ Přinejmenším pro čtenáře, který není zasvěcen do desítky let trvajících historických diskuzí o charakteru moderních diktatur tak může vcelku snadno vzniknout dojem, jako by Michal Pullmann ve svém pohledu na státní socialismus reprezentoval jakousi anomálii. Obraz Pullmannovy koncepce jakožto svérázného a osamělého pokusu o reinterpretaci minulosti Matej Cíbik, at' už úmyslně, či mimoděk, prohlubuje nejen mlčením o širokém proudu historiografie státního socialismu (včetně jeho pozdní fáze), jež poukazuje na každodenní vyjednávání i zdroje legitimity tohoto společenského a politického uspořádání, ale také konkrétními formulacemi sugerujícími svébytnost Pullmannova př́stupu. Především pokud se jedná o „Pullmannovo opakované a časté používání významných politicko-filosofických termínů jako konsensus, legitimita či společenská smlouva“.9

Měřeno tendencemi historiografie západního světa zhruba od druhé poloviny šedesátých let, je tomu však právě naopak. Michal Pullmann a mnozí další čeští historikové a historičky ${ }^{10}$ převážně mladší a střední

8 M. Cíbik, Michal Pullmann a filosofické aspekty sporu o charakter normalizace, str. 174-175.

9 Tamt., str. 173.

10 K výrazným kulturně a sociálně historickým pracím vztahujícím se k období státního socialismu (vedle textů M. Pullmanna či P. Koláře) patří např. oceňovaná kniha Petra Roubala o československých spartakiádách (P. Roubal, Československé spartakiády, Praha 2016) nebo výsledky výzkumu Martina France a Jiřího Knapíka (M. Franc - J. Knapík, Volný čas v českých zemích 1957-1967, Praha 2013), sociálně historický př́istup zdůrazňující kontinuity s předválečným a válečným obdobím aplikují např. R. Šustrová a J. Rákosník (J. Rákosník - R. Šustrová, Rodina v zájmu státu. Populační růst a instituce manželství v českých zemích 1918-1989, Praha 2016), na pomezí sociálních dějin a dějin vědy pak k výzkumům inspirovaným revizionistickými či postrevizionistickými př́stupy patří studie V. Sommera (V. Sommer, Angažované dějepisectví. Stranická historiografie mezi stalinismem a reformním komunismem 
generace pro případ české socialistické diktatury aplikují a v některých aspektech snad prohlubují perspektivu, která je výrazně rozššŕrenější a která je v historické obci v posledních desetiletích zpravidla vnímána jako přesvědčivější než např́íklad práce vycházející z teorie totalitarismu. Jak je alespoň mezi historiky soudobých dějin všeobecně známo, již někteří američtí sovětologové šedesátých a sedmdesátých let dvacátého století akcentovali z hlediska hodnotových postojů i strategií jednání relativně pestrou každodennost lidí v socialistické diktatuře a jejich podíl na utváření legitimity diktatury. Ve svých pracích se pochopitelně zabývali převážně sovětským stalinismem, proto jejich přístupy a interpretace nelze př́imočaře aplikovat na pozdní socialismus. Není ale bez zajímavosti, že už některé tyto pramenně pečlivě podložené studie o nejbrutálnějším období v dějinách sovětské socialistické diktatury poukazují na některé aspekty podstatné i pro Pullmannovy a další sociálně a kulturně historické práce o pozdějších fázích státního socialismu, v SSSR i za jeho hranicemi.

V Česku je i mezi zainteresovanými laiky zřejmě nejznámější postavou tohoto proudu Sheila Fitzpatricková, která prostřednictvím detailního studia široké palety pramenů vykreslila plnokrevný obraz stalinské každodennosti a mimo jiné (spíše empiricky než prostřednictvím bytelnější teoretické reflexe) ukázala nejen variabilitu životních a politických strategií aktérů, ale i skutečnost, že tmelem sovětského režimu nebyly totalitní ambice centra, nýbrž osvojení komunistické utopie ve společenské praxi. Máme ostatně to štěstí, že Fitzpatrickové monografie vycházející z jejího vůbec nejrozsáhlejšího výzkumného projektu, Každodenní stalinismus, byla publikována i v češtině. ${ }^{11} \mathrm{I}$ z hlediska soudržnosti československé normalizace mohou být inspirativní např́klad Fitzpatrickové výzkumy tzv. vydviženců, původně dělníků a rolníků, kteří se díky masivní podpoře vzdělání dostávali koncem dvacátých let do významných funkcí. Fitzpatricková zdůrazňovala, že většina lidí, kteří profitovali

1950-1970, Praha 2011, a zejm. V. Sommer a kol., Řídit socialismus jako firmu. Technokratické vládnutí v Československu, 1956-1989, Praha 2019). Marián Lóži, Jakub Šlouf a Matěj Bílý prezentují KSČ jako mnohovrstevnatý organizmus s různými skupinami autonomně jednajících aktérů a to dokonce i v období první poloviny padesátých let (M. Bílý - M. Lóži - J. Šlouf, Regionální elity a komunikace uvnitř KSČ v letech 1945-1956, Praha 2019). Mezi další autory, kteří se k těmto inspiracím přímo hlásí, nebo z nich přinejmenším čerpají, patří J. Mervart, P. Houda, J. Mrňka, J. Janáč, D. Nečasová a mnozí další.

11 S. Fitzpatrick, Každodenní stalinismus. Obyčejný život v neobyčejné době. Sovětské Rusko ve 30. letech, přel. T. Trusina, Praha 2018 (anglický originál Everyday Stalinism byl vydán r. 1999). 
z prudké sociální mobility, nový systém nadšeně přijímala a považovala jeho heroické výkony na poli industrializace, upevnění sovětské moci i pozdějších vojenských vítězství za svůj vlastní úspěch. O jejich hodnotový konzervatismus se prritom opíral jak teror třicátých let, tak i kulturní a politická strnulost období pozdějších. ${ }^{12}$

Navzdory jinému kontextu můžeme vidět paralelu v tom, že i československé čistky přelomu šedesátých a sedmdesátých let měly za důsledek sociální vzestup spojený s kariérním postupem desetitisíců až statisíců těch, kdo obsadili uprázdněná místa. Kombinace vděku a hodnotového konzervatismu těchto nových funkčních elit hrála poměrně významnou roli a těžko si představit, že vzhledem $\mathrm{k}$ tomuto faktu normalizační uspořádání nemělo jejich alespoň tichou podporu. ${ }^{13}$

Možná ještě větší vliv na Pullmannovu badatelskou perspektivu než generace revizionistů měli tzv. postrevizionisté, a to nejen proto, že se tématem některých z nich od devadesátých let stala i pozdní fáze socialistických diktatur. Důležitější je pozměněné kladení otázek a jiné (spíše kulturně historické, resp. lingvistickým obratem ovlivněné) rozumění problematice jazyka a ideologie. Pro většinu revizionistů totiž ideologie, paradoxně podobně jako pro zastánce totalitaristických přístupů, představovala doktrinální systém pouček a věr - na rozdíl od Arendtové a dalších pouze upozorňovali na to, že mysl aktérů tímto systémem nemusela být plně kolonizována a poukazovali na autonomii jejich myšlení a jednání. Postrevizionisté přestali ideologii chápat jako cosi vnějšího, co zastírá skutečné zájmy těch, kdo ideologii využívají a reprodukují, a co občany bud' plně ovládá, vymezuje jim hranice, nebo je jimi užíváno pouze jako falešná maska. Historičky a historici jako Wendy Goldmanová ${ }^{14}$ nebo Stephen Kotkin ${ }^{15}$ v devadesátých letech poskytli fascinující vhled do praxe osvojování ideologického jazyka. Pojem osvojování je zde klíčový, protože se nejedná ani o bezduché přejímání či dokonce

12 S. Fitzpatrick (vyd.), Cultural Revolution in Russia 1928-1931, Bloomington 1978. Viz k tomu M. Pullmann, Doslov, in: W. Z. Goldmanová, Vytváření nepřitele. Udávání a zastrašování ve stalinském Rusku, přel. J. Spurná - M. Spurný, Praha 2015, str. 267-286, zde str. 273-276.

13 K pojmu „funkční elity“ viz A. Lüdtke, Funktionseliten. Täter, Mit-Täter, Opfer? Zu den Bedingungen des deutschen Faschismus, in: týž (vyd.), Herrschaft als soziale Praxis, Göttingen 1991, str. 559-590.

14 V češtině zatím vyšlo: W. Z. Goldmanová, Vytváření nepřitele.

15 Jeho nejslavnější dílo představuje monografie o budování Magnitogorsku v éře vrcholného stalinismu: S. Kotkin, Magnetic Mountain. Stalinism as a Civilization, Berkeley - Los Angeles 1995. 
úplné ztotožnění se, ale ani o pouhé instrumentální užívání určité formy, kterou by pak lidé mohli $\mathrm{v}$ případě potřeby opět odložit. Téma zacházení $\mathrm{s}$ jazykem je jedním z bodů předložené polemiky, proto se $\mathrm{k}$ němu vrátíme. Zde jsem chtěl pouze poukázat na inspirační zdroje a širší kontext Pullmannovy argumentace.

Jestliže se většina dosud zmiňovaných autorek a autorů primárně věnovala problematice vrcholného stalinismu, jež je od tématu normalizačních poměrů dosti vzdálená, je třeba na tomto místě zmínit dva zcela zásadní inspirační zdroje pro interpretační rámec pozdního socialismu, jaký nabízí Michal Pullmann. Těmi jsou studie a celkový přístup rusko-amerického antropologa Alexeje Jurčaka a německého historika Martina Sabrowa.

V osmdesátých letech dvacátého století byl mladý leningradský fyzik Alexej Jurčak členem tamní alternativní scény. Ve své knize Bylo to na věčné časy, dokud to neskončilo ${ }^{16}$ i pozdějších studiích - to již jako promovaný kulturní antropolog působící na universitě v Berkeley - nabídl právě antropologickou perspektivu a obohatil ji využitím postupů historiografie soudobých dějin, přičemž jeho východiska mají bezpochyby i autobiografické, zkušenostní zázemí. Pomocí pečlivé rekonstrukce pozdně socialistického jazyka Jurčak ve svých studiích ukazuje, že se mnoho sovětských občanů na jedné straně upřímně ztotožňovalo s klíčovými ideály socialismu, jako byly rovnost, pospolitost, solidarita nebo přátelství, ale že se titíž lidé zároveň ve svém každodenním životě od oficiální ideologie distancovali nebo si ji vykládali po svém. Obojí se dělo, tvrdí Jurčak - a explicitně přitom polemizuje is Václavem Havlem,$-{ }^{17}$ aniž by to nutně muselo znamenat přetvářku či lhaní. Nástroj, jak vysvětlit tyto zdánlivé paradoxy, Jurčakovi poskytuje Bachtinův výměr „,autoritativního diskursu“ ${ }^{18}$ jehož funkce, jak Jurčak ukazuje, se změnila v letech kolem Stalinovy smrti. Oslabující konstativní a posilující performativní funkce řečových výpovědí podle něj na jedné straně oslabovaly možnost reálné proměny a řešení prohlubujících se problémů sovětské společnosti, zároveň ale zajišt'ovaly stabilitu. Prolínání identifi-

16 A. Jurčak, Bylo to na věčné časy, dokud to neskončilo. Poslední sovětská generace, přel. P. Houda - V. Bránišová, Praha 2018. Anglický originál Everything Was Forever, Until It Was No More. The Last Soviet Generation byl publikován r. 2005.

17 A. Jurčak, Bylo to na věčné časy, str. 31-32.

18 Jurčak vychází zejména z: M. M. Bakhtin, The Dialogical Imagination. Four Essays by Mikhail Bakhtin, přel. C. Emerson - M. Holquist, Austin 1994, z Bachtinových do češtiny přeložených textů pak také cituje: M. M. Bachtin, Dostojevskij umělec. K poetice prózy, přel J. Honzík, Praha 1971. 
kace s některými hodnotami socialismu, alternativních výkladů vládnoucí ideologie a svévolného zacházení s nimi v praxi ovšem skýtá potenciál vysvětlit nejen dlouho trvající stabilitu sovětského režimu, která podle Jurčaka, jak z výše řečeného vyplývá, nebyla jen vynucená či předstíraná, ale i jeho poměrně rychlou implozi na konci osmdesátých let.

Ačkoliv se Martin Sabrow na rozdíl od Alexeje Jurčaka nezabýval alternativními skupinami či populární kulturou, ale převážně vnitrostranickými diskursy a politikou paměti, a to navíc v bývalé NDR, jeho argumentace se v podstatných aspektech té Jurčakově podobá. Především to platí, pokud jde o problematiku ,inscenování jednoty“ či dokonce „vášně pro jednomyslnost“" v pozdně socialistické diktatuře. ${ }^{19}$ Sabrow ukázal, jak tento důraz na (vnějškovou) jednotu spoluurčoval rétoriku i praxi stranické politiky, ale také jak pronikal do životní praxe lidí v oblasti estetiky nebo materiálního života - což se proti režimu mohlo obrátit např́íklad v podobě rozhořčení nad třeba jen drobnými privilegii stranických elit nebo kterékoli jiné profesní skupiny. Jak ještě blíže ukážu, také Sabrow, podobně jako Michal Pullmann, pro tento aspekt pozdně socialistické diktatury užívá pojem konsensus - i on tak skrze rozpad tohoto konsensu vysvětluje zhroucení socialistických diktatur v pozdních osmdesátých letech.

Pochopitelně, i pokud přistoupíme na Jurčakovu či Sabrowovu argumentaci, nabízí se otázka specifičnosti československé společnosti a pilir̂ru stability zdejšího mocenského uspořádání, jež mohly v důsledku živé zkušenosti pražského jara a následné okupace země oproti východoněmecké a zejména sovětské skutečnosti vykazovat některé významné odlišnosti. Na druhou stranu ovšem není důvod se domnívat, že v Československu, jako sovětském satelitu, ,,autoritativní diskurs“ fungoval diametrálně odlišným způsobem než v Sovětském svazu a dalších zemích fungujících pod přímým dohledem Moskvy. K místním specifikům jistě patří postupné poddolování jeho autoritativní povahy a odklon od ritualizovaného stvrzování v průběhu reformních šedesátých let - a bylo by na samostatnou úvahu, nakolik je možné Pražské jaro interpretovat také jako rozklad režimu autoritativního diskursu obdobně, jak o něm právě Jurčak píše v souvislosti se sovětskou perestrojkou. Nicméně pokud jde o následné období normalizace, shodnou se historici zastávající různé badatelské perspektivy na poměrně těsné závislosti československého oficiálního diskursu na tom sovětském. A to nejen pokud jde o (ostatně méně

19 M. Sabrow, Socialismus jako myšlenkový svět. Komunistická diktatura v kulturně historické perspektivě, př̀l. P. Kolár̆, in: Soudobé dějiny, 19, 2012, str. 196-208. 
podstatnou) obsahovou rovinu, ale především pokud jde o performativní stránku, tedy způsob, jakým byly ,pravdy“ zjevovány a jak se s nimi v médiích, na schůzích i jinde, zacházelo. Stejně platí v československém prostředí to, co Jurčaka dovedlo k jeho ústřední otázce, totiž paradox nečekanosti konce státního socialismu a zároveň připravenosti velké většiny lidí na tuto radikální změnu. I zde přitom můžeme jako jeden z důvodů shledávat důraz na performativní funkci jazyka a stvrzování oficiálního diskursu, jež zároveň v praxi připouštěly rozšiřování spektra toho, co bylo možné pojmout do rámce socialistických hodnot. Od angažovaného kolektivismu až po opevňování se v soukromých prostředích a radikální individualismus, od vyznávání klasické buržoazní kultury v duchu devatenáctého století až po lokální adaptace alternativních západoevropských a amerických kulturních proudů. Shodná je i tendence dobových ideologů, disentu a zejména postsocialistické politiky a historiografie líčit státní socialismus prostřednictvím dichotomických modelů ovládajících a ovládaných, loajálních přisluhovačů a odvážných odpůrců.

Kulturně historická i antropologická východiska, která jsem v předcházejících odstavcích předvedl na příkladu dvou autorů, jejichž texty jsou pro př́ípadné zájemce $\mathrm{k}$ dispozici dokonce i v češtině, využívá Michal Pullmann spolu s dalšími pro analýzu normalizačního uspořádání. V souladu s výše uvedenými i dalšími autory a autorkami přitom klade důraz na zdroje legitimity socialistické diktatury, na specifickou podobu konsensu a na performativní funkci jazyka v rámci stvrzování a spoluutváření ideologie v éře pozdního socialismu. Právě tyto dva aspekty Matej Cíbik nejrozhodněji rozporoval, je tedy třeba se k nim krátce vrátit.

\section{Legitimita diktatury a dynamika ideologie}

Matej Cíbik rozporuje Pullmannovu tezi o legitimitě československého státního socialismu v sedmdesátých a osmdesátých letech. Zatímco Michal Pullmann podle Cíbika z faktu ,tiché podpory“ většiny obyvatelstva normalizačnímu režimu odvozuje jeho legitimitu (ve weberiánském, tj. analytickém smyslu toho pojmu), poukazuje Cíbik na skutečnost, že i víra v legitimitu, jak ji definuje Max Weber, musí být skutečná. Cíbik v této souvislosti poměrně vyostřeně obviňuje Pullmanna, že jeho (a Kolářova) ,pozice se zakládá na nepř́liš̌ přesvědčivé interpretaci [Webera]““.20

20 M. Cíbik, Michal Pullmann a filosofické aspekty sporu o charakter normalizace, str. 175 . 
Nepř́ísluší mi odpovídat stejným tónem a podobně autoritativně tvrdit, že naopak Cíbik vykládá Webera chybně, avšak je třeba alespoň upozornit, že interpretace Weberovy „víry v legitimitu“, kterou M. Cíbik nabízí, není zcela v souladu s myšlenkovou tradicí, v níž tkví kořeny Weberova myšlení. Víra v určitý společenský řád (tj. víra v nenáboženském, přeneseném slova smyslu) se v rámci této myšlenkové tradice neodvozuje od toho, co o ní (resp. o panujících poměrech) aktéři prohlašují, ale je třeba ji interpretovat skrze jejich jednání. Weber v té souvislosti poukazuje na stvrzování stávajícího panství formou osvojování si a akceptování, čímž chce předvést, že legitimita je zakládajícím znakem každého dlouhodobě fungujícího panství. Vzhledem k tomuto výkladovému rámci vztahu státu a společnosti nepřekvapí, že Weber nikde nemluví o „nelegitimním panstvî“ (illegitime Herrschaft). Tváří v tvář moderním diktaturám se takové pojetí může jevit jako znepokojivé. To je zcela na místě. Právě důraz na akceptování podřízenosti a osvojování konformního jednání či ideologie opravdu nelakuje skutečnost na růžovo, ale naopak vposledku poukazuje na velmi varovné souvislosti. Navzdory možnému prvotnímu dojmu takto široký výměr legitimity přitom není vyprázdněný. Vede nás totiž ke zcela zásadním otázkám, na čem se legitimita v různých historických situacích zakládá, jak se proměňuje, prostřednictvím jakých nástrojů je posilována, nebo proč se naopak rozpadá (aby se záhy rozpadlo i panství na ní založené).

Prohlubování této teoretické rozpravy by nás nedovedlo ke konkrétní argumentaci týkající se normalizace, jak ji formuloval Matej Cíbik. Proto mi nezbývá než zůstat u tohoto konstatování. Užití legitimity u Maxe Webera nicméně v této souvislosti již před třemi lety $\mathrm{v}$ odpovědi na text Miloše Havelky pojednal Pavel Kolář v časopise Soudobé dějiny. ${ }^{21}$

Podstatnější pro tuto naši polemiku je skutečnost, že ani v interpretačním rámci, který si Cíbik sám vykolíkoval, nelze - ani při velmi vstřícném čtení - přijmout jeho argumentaci proti tezi o vnitřních, společenských zdrojích legitimity a existenci „tichého souhlasu“. Abych vysvětlil proč, musím zde ve zkratce Cíbikovu argumentaci v tomto bodě rekapitulovat:

Abychom podle Mateje Cíbika v případě normalizační společnosti mohli tvrdit, že existovala víra v legitimitu (v souladu s jeho výkladem Weberova pojetí), musela by $\mathrm{v}$ dané době existovat reálná možnost dát najevo ztrátu, resp. absenci takové víry. Takovou možnost pro Mateje

21 P. Kolár̆, Normalizace ve své epoše. V odpověd' na polemiku Miloše Havelky, in: Soudobé dějiny, 25, 2018, str. 523-536. 
Cíbika v liberální demokracii představují svobodné volby (tj. např. volba antisystémových politických stran). Autor však přiznává, že ve filosofické tradici najdeme i autory, pro něž, tak jako např́klad pro Platóna, „,spokojený pobyt v obci ... představuje jistou formu praktické afirmace, jíž se stvrzuje legitimita daného politického uspořádání a autorita jeho zákonů.“22 Tento postoj, připomíná Cíbik, v novověku zastával a dále rozpracoval např. John Locke, oponoval mu naopak David Hume, který poukázal na praktické obtíže (a tudíž jistou vykonstruovanost) takové volby. Řada lidí má podle Huma asi takovou reálnou možnost místo svého pobytu opustit jako pasažér lodi uprostřed oceánu:

„Jestli právo na emigraci je, nebo není dostatečnou podmínkou pro existenci tichého souhlasu, je však v kontextu normalizace veskrze akademickou otázkou. Režim, který na hranicích stř́lel vlastní občany, žádný prostor pro rozhodnutí nedával. Obyvatelé Československa byli proto jednoznačně v situaci Humova muže, kterého v hlubokém spánku přenesli na lod', jež v mezičase vyplula a ted’ se nachází uprostřed oceánu. Absence jakéhokoli elementu svobodného rozhodování znamená, že i následné smírení velké části populace se svou situací nic nevypovídá o akceptaci či legitimitě normalizačního režimu." 23

Aniž bych chtěl dialog zbytečně zatěžovat reáliemi, zde mi nezbývá než přece jen zmínit některá historická fakta, nebot' autorův argument je vposledku historické, nikoli filosofické povahy. Ačkoli to může působit jako detail, jeví se mi zároveň symptomatické, že celá poměrně náročně vystavěná filosofická argumentace stojí na krajně nepřesné charakteristice historické reality: Argument, že „režim, který na hranicích střílel vlastní občany, žádný prostor pro rozhodnutí nedával“", resp. že se dokonce jednalo o absenci ,jakéhokoliv elementu svobodného rozhodování“, neobstojí ani tváří v tvář žité paměti tisíců rodin, jejichž příslušníci dodnes vzpomínají, že emigrace (přes Jugoslávii, Bulharsko atd.) byla reálně zvažovanou možností, ani v konfrontaci s historickými prameny. Nejde jen o to, že zhruba rok po okupaci Československa byla cesta do emigrace zcela otevřená - a lidé onen rok zpravidla, budeme-li se držet obrazu Humova muže na palubě, neprospali. Od konce léta 1969 Čes-

22 M. Cíbik, Michal Pullmann a filosofické aspekty sporu o charakter normalizace, str. 176.

23 Tamt., str. 177. 
koslovensko jako většina komunistických diktatur opět obsesivně a tvrdě střežilo své hranice a cestování bylo spojeno s řadou obtěžujících, někdy i ponižujících procedur. Avšak v následujících dvou dekádách i tak milióny Čechů a Slováků vyjížděly za hranice země. Sám jsem byl v rámci bádání o tehdejším universitním prostředí překvapen, $v$ jaké šîri byly i v tomto období realizovány studijní pobyty v západoevropských zemích. Díky existujícím syntetičtějším výzkumům můžeme množství cest do zahraničí i kvantifikovat. Jak uvádí Jan Rychlík, československé hranice překračovalo na přelomu sedmdesátých a osmdesátých let ročně zhruba pět miliónů lidí, statisíce do západních zemí nebo do zemí, z nichž se dalo na Západ bez větších obtíží odejít (Jugoslávie). Zhruba pět tisíc z nich přitom každý rok emigrovalo. ${ }^{24}$

Pokud by se tedy argumentace proti tezi o existenci tichého souhlasu výrazné části společnosti skutečně měla opírat o praktickou nemožnost jednat jinak, musela by povolat ke své podpoře jiné historické skutečnosti. Obávám se ovšem, že takové se budou hledat obtížně. Za subversivní jednání či vzepření se panujícímu uspořádání jako takovému se platí v každém systému, $\mathrm{v}$ roce $1980 \mathrm{v}$ řadě případů sice bolestivěji než o deset či dvacet let později, ovšem evidentně méně bolestivě než o třicet či čtyřicet let dříve. Kde leží hranice, která nám dovoluje mluvit o „absenci jakéhokoli elementu svobodného rozhodování“? Pokud moment svobodného rozhodování nepřiznáme obyvatelům pozdně socialistického Československa, jak jejich situaci v tomto ohledu odlišíme např́klad od otroků v někdejším belgickém Kongu, vězňů nacistického koncentračního tábora, zajatců na americké základně Guantánamo nebo současných obyvatel Severní Koreje? Neochuzujeme se prostřednictvím podobných absolutních soudů a dichotomií (společenské uspořádání je bud' svobodné a legitimní, nebo zcela nesvobodné a nelegitimní) o analytické nástroje, které mohou být významnou pomůckou pro porozumění společenské dynamiky a legitimity panství v různých fázích existence rozmanitých forem vládnutí?

V souvislosti s osvojováním a používáním ideologického jazyka si Matej Cíbik všímá paralel i rozdílů mezi Havlovou a Pullmannovou analýzou. Není první. Sám Michal Pullmann o tom, v čem se shoduje s pozorováním pronikavých svědků oné doby, jakými bezpochyby byli Václav Havel nebo Milan Šimečka, často hovoří. I výše zmiňovaný Ale-

24 J. Rychlík, Cestování do ciziny v habsburské monarchii a v Československu. Pasová, vízová a vystěhovalecká politika 1848-1989, Praha 2007, str. 107-121. 
xej Jurčak upozorňuje na Havlovu nebo také Charchodinovu ${ }^{25}$ analýzu rituálního používání ideologických floskulí, aby se následně, podobně jako Pullmann, distancoval od podle něj zjednodušující a účelové dichotomie života $\mathrm{v}$ pravdě a života ve lži. Tyto modely sdílejí zásadní problém:

„Ačkoli k jedné binární opozici (přijetí / nepřijetí ideologie) nabízejí alternativu, činí tak způsobem, jenž vytváríi další problematické binární opozice - ,pravda“ / ,lež‘, ,realita“ / ,maska“, ,odhalování" / ,přetvařování‘. Podle těchto binárních modelů bychom měli veřejné politické akty, jakými jsou hlasování pro oficiální rezoluci či vyvěšení provládního hesla na manifestaci, interpretovat ,doslovně - jako deklarace faktu, že daný subjekt podporuje stát. Tyto deklarace jsou pak bud’ pravdivé (vyjadřují ,skutečnou' podporu), nebo falešné (podporu ,předstírají). V základech takového porozumění leží některé problematické axiomy, jež se týkají povahy jazyka, vědění, významu a subjektu. Z tohoto hlediska je jedinou funkcí jazyka vztahovat se k již existujícímu světu a konstatovat fakta... Chceme-li dojít k jemnějšímu chápání pozdního socialismu a jeho paradoxů, potřebujeme se dostat ,za' tyto problematické axiomy a prozkoumat, jak se lidé v tomto systému angažovali, jak jej interpretovali a jakou realitu si v něm vytvářeli.“26

Tuto kritiku, jak jsem již výše naznačil, Matej Cíbik částečně sdílí a sám zmiňuje, že ritualizované užívání jazyka, kdy se mluvčí spíše hlásí k určitému kódu či sounáležitosti či obeznámenosti s pravidly, než že by mu skutečně šlo o obsah řečeného, můžeme pozorovat $\mathrm{v}$ jakémkoli společenském uspořádání a že tento fakt neodlišuje např́íklad pozdně socialistickou diktaturu od liberální demokracie. Cíbik ale nesouhlasí s rozšîrenou kulturně historickou (v jeho pojetí ovšem specificky Pullmannovou) perspektivou, že lidé i v diktatuře prostřednictvím osvojeného ideologického jazyka vyjednávali s mocí, někdy dosahovali svých cílů a podíleli se i na postupné proměně myšlení či ideologie. Podle Cíbika je vyjednávání s mocí „V podmínkách diktatury, pomocí formalizovaného jazyka, jímž tato moc vždy mluví výrazně lépe než občan“ téměř nemožné a „Pullmannovo nadnesené tvrzení, že občané dokáží prostřednictvím ideolo-

25 O. Kharkhordin, The Collective and the Individual in Russia. A Study of Practices, Berkeley 1999.

26 A. Jurčak, Bylo to na věčné časy, str. 31-32. 
gického jazyka přimět režim, aby plnil jejich ,požadavky‘ a respektoval jejich ,postoje‘, je proto nutné korigovat“ ${ }^{27}$ Zásadní rozdíl mezi různými jazykovými kódy například v prostředí liberálního kapitalismu a normalizačním ideologickým jazykem pak Cíbik spatřuje jednak v údajné bezobsažnosti normalizačních floskulí a zároveň v mocenském kontextu, tj. skutečnosti, že vyžadovaný jazyk veřejné komunikace v normalizační éře ,potřeboval represivní aparát, který potlačoval všechny alternativy a nutil (či ,motivoval') lidi jej používat". 28

Podobně jako v prvním prípadě staví Cíbik svůj argument na poměrně vyhroceném pojetí normalizační reality, tedy na svém vlastním soudu o dějinách. Skutečně represivní aparát pozdně socialistického režimu „potlačoval všechny alternativy“? Pozdně socialistická realita byla ve skutečnosti plná nejrůznějších komunit s vlastním jazykovým kódem, od hudebních subkultur, přes Klub za starou Prahu až po ekologické aktivisty z hnutí Brontosaurus. Prostřednictvím důkladného studia těchto skupin můžeme, podobně jako to činil Alexej Jurčak na prríkladu leningradského archeologického kroužku či prostředí tamní technické inteligence, skutečně sledovat, jakým zpơsobem občané prostřednictvím oficiálně zaužívaných formulací opírajících se o dominantní ideologii byli schopni otevírat nové možnosti pro svoje individuální i kolektivní jednání. Sám jsem takové postupy popsal mimo jiné na př́kladu ekologické žurnalistiky (časopis Nika) a environmentálních aktivit sedmdesátých i osmdesátých let. ${ }^{29}$ Jak jsme ukázali prostřednictvím výzkumu o Filozofické fakultě Univerzity Karlovy v normalizační ére,$^{30}$ nemuselo navíc nutně platit ani to, že moc mluví formalizovaným jazykem „výrazně lépe než občan“. ${ }^{31}$ Řada zejména vzdělaných lidí, včetně opozičních aktivistů, ovládala ve skutečnosti oficiální jazyk výrazně bravurněji než např́klad agenti Státní bezpečnosti, kteří je vyslýchali, z čehož vznikalo mnoho tragikomických příhod, ale někdy opravdu i argumentační převaha, jež v příslušném vztahu (i tak mocensky asymetrickém jako je situace vyslýchajícího a vyslýchaného) mohla sehrát důležitou roli. Tím spíš pak umění zacházet s ideologickým

27 M. Cíbik, Michal Pullmann a filosofické aspekty sporu o charakter normalizace, str. 185 .

28 Tamt., str. 187.

29 M. Spurný, Mezi vědou a politikou, in: M. Kopeček (vyd.), Architekti dlouhé změny. Expertní kořeny postsocialismu v Československu, Praha 2019, str. 267-313.

30 J. Jareš - M. Spurný - K. Volná a kol., Náměstí Krasnoarmějců 2.

31 M. Cíbik, Michal Pullmann a filosofické aspekty sporu o charakter normalizace, str. 185. 
jazykem napomáhalo k dosahování dílčích cílů v méně „,represivních“ situacích, jako bylo vyjednávání o uspořádání hudebního festivalu Porta, podpora studijního pobytu vlastních studentů v západní Evropě nebo třeba argumentace pro záchranu větší části zástavby pražského Žižkova. Moc nebyla všemocná a nepředstírané vyjednávání ze strany lidí obeznámených s neformálními pravidly používání ideologického jazyka nalezneme téměř v každém koutě normalizační reality.

Pro Cíbikovu argumentaci je charakteristické konstruování dichotomií (legitimní a nelegitimní vláda, skutečný konsensus a tichý nesouhlas, svobodná volba způsobu promlouvání a jeho represivní vynucování), do nichž se pak snaží vtěsnat historickou realitu. Zatímco v naší současnosti spatřuje př́íklad legitimní vlády a dosahování konsensu podmíněného možností svobodné volby, naplňují pro něj normalizační poměry kritéria antagonistického modelu, tj. nelegitimní vlády obsluhující se pouze vynucovaným přitakáváním jakýchsi nedobrovolných pasažérů. Prostřednictvím některých historických reálií a příkladů, na jejichž obšírnější rozvedení v tomto textu ovšem nebyl prostor, jsem se pokusil ukázat, že Cíbikovy vposledku historické soudy o dobové realitě (na nichž pak staví filosofickou argumentaci) se př́liš nepotkávají s výsledky pramenného výzkumu o éře normalizace. Zdá se však, že hlavní prríčina odlišných stanovisek či jistého míjení spočívá v odlišných postupech vlastních našim oborům, jež mají vliv i na to, jak myslíme a rozumíme dějinám. Zatímco filosof je zvyklý pomocí jednoznačných odpovědí na otázky dospívat ke kategorickému a začasté i normativnímu soudu, historik (a tím spíše sociální či kulturní historik) pracuje s mnohovrstevnatostí společenské reality a jejími dynamickými proměnami v čase. Tam, kde si filosof klade otázku, zda politický režim byl, či nebyl legitimní, budeme jako historici raději analyzovat možné zdroje legitimity a zjišt'ovat, jak se během sledovaného období (třeba i normalizačního dvacetiletí) proměňovaly. A tam, kde filosof (či politolog) dospěje porovnáním reality s modelem či předem definovanými kategoriemi k tvrzení, že určité politické uspořádání bylo nesvobodné (nebo naopak svobodné), budeme jako historici vyprávět o podobách a zkušenostech znesvobodňování i osvobozování, které často nacházíme vzájemně propletené podivuhodně blízko sebe.

\section{Dějiny a současnost}

Otázky, které minulosti klademe, pojmy, které používáme, a způsoby, jakými interpretujeme lidské jednání, v posledu vyrůstají z našeho hod- 
notového zakotvení. Není žádný důvod, aby tomu tak nebylo rovněž v případě sporu o legitimitu či možnosti vyjednávání v pozdním socialismu. Většina aktérů dosavadních debat o revizionismu v českém dějepisectví tento aspekt dosud zmiňovala bud’ velmi povrchně (spíše ve snaze stigmatizovat jednotlivé autory např. jako ,postmarxisty“ či rovnou „bolševiky“), nebo raději vůbec ne. Jako sociální a humanitní vědci se zpravidla zdráháme našim kolegům a kolegyním (a tím spíše sami sobě) připomínat jejich či naši vlastní, metodologicky nepohodlnou, zaujatost, jejíž tematizování nás činí zranitelnějšími a jež bude v případě historiků a historiček nutně vzbuzovat podezření z nepř́ípustného prezentizmu a instrumentalizace dějin.

Navzdory sebepoctivější snaze o neutrální historizaci nedávné minulosti bude ovšem náš pohled vždy výrazně spoluformován tím, zda současný politický a ekonomický systém vnímáme primárně jako výsledek svobodného rozhodnutí a cestu k emancipaci či důstojnému životu pro všechny, či naopak spíše jako uspořádání charakteristické koncentrací moci a kapitálu, s výraznou komponentou odcizení a znesvobodňování. V prvním př́ípadě budeme mít tendenci $\mathrm{k}$ dichotomiím, $\mathrm{v}$ jejichž rámci bude současnost vzorem „,svobodného uspořádáni““, zatímco jiné modely budou spadat do kategorie nesvobodných, nelegitimních či represivních režimů - to se do jisté míry přihodilo i Mateji Cíbikovi. Ten např́íklad konstruuje principiální rozdíl mezi normalizačním a současným jazykovým kódem s odkazem na to, že ,jazyk demokracie a individuálních šancí se prosadil v podmínkách svobody slova“", podobně vyzvedává „férové volby“, které se podle něj konají v kapitalistických podmínkách. Efektivní fungování kapitalistické ekonomiky pak Cíbik považuje za důsledek vysoké vnitřní motivace pracujících, kreativity vyrůstající zdola a obecně „měkkých faktorů“, které nelze řídit a kontrolovat z jednoho centra. Co přesně nám ale vyšší flexibilita, motivovanost či výkon pracujících v podmínkách liberálního kapitalismu (oproti pozdní normalizaci) říká o legitimitě současného panství, není vůbec jasné. Jak známo, to, co Cíbik považuje za svobodné přijetí a vnitřní motivaci, jiní autoři interpretují jako sebedisciplinaci, která je efektivním nástrojem moderního vládnutí. ${ }^{32}$ Vládnutí, v jehož neoliberální variantě se člověk stává dispo-

32 Klasickou práci v tomto ohledu představuje pochopitelně M. Foucault, Zrození biopolitiky, přel. P. Horák, Brno 2009, vycházející z Foucaultových přednášek pronesených v Pařízi r. 1979, viz k tomu recenzi: J. Růžička, Michel Foucault. Zrození biopolitiky, in: Reflexe, 37, 2009, str. 132-142. Ještě o něco dříve, než Foucault pronesl své legendární přednášky k tématu biopolitiky, vyšla v USA práce Garyho Beckera, v níž se autor zaměřil na sebedisciplinaci a ekonomickou redukci člověka a lidského 
nibilním subjektem - bytostí, jež sama sebe redukuje tak, aby maximalizovala svoji využitelnost na pracovním trhu. Jakkoli ideologie, o níž se dnešní systém opírá, zpravidla není jakožto ideologie vnímána a není většinou autoritářsky vynucována (byt' například popírání vlastnických práv je rovněž možné kriminalizovat), zajišt'uje si výrazně efektivněji svoji hegemonii jinými prostředky. Jak již v šedesátých letech upozornil Ladislav Hejdánek, „měrou, jakou se zmenšuje možnost i nutnost tvrdého mocenského zákroku, zvyšují se požadavky na kvalitní ideologii. Ideologie je však tím účinnější, čím méně vystupuje jako ideologie proti neideologickému myšlení.“33

Prostředky reprodukce a udržování hegemonie současné ideologie, ačkoli jsou výrazně sofistikovanější než v dobách normalizačního autoritářství, ovšem rovněž nepostrádají mocenské aspekty. Politická moc je sice kontrolována prostřednictvím soutěže více politických subjektů v různých typech voleb a její jednotlivé pilî́re jsou odděleny, o to výraznější je ovšem koncentrace jen dílčím způsobem kontrolovatelné ekonomické moci. Ta vytváří zásadní nerovnosti a z participace a svobodné volby činí v řadě oblastí značně formální záležitost. Myslet si, že koncentrace ekonomické moci na straně těch, kdo si z pochopitelných důvodů přejí zachování stávajícího řádu, nemá vliv na „férové volby“, znamená z mého pohledu procházet současný svět (neo)liberálního kapitalismu, se všemi jeho ostrými kontrasty mezi mocí a bezmocí, s klapkami na očích.

Otázka, jak je to v našem současném systému s opravdovou vírou v legitimitu vládnoucích elit - jež nelze redukovat na elity v úzkém slova smyslu politické -, v tom smyslu, jak této viře rozumí Matej Cíbik, je tak přinejmenším podobně zapeklitá, jako v podmínkách socialistické diktatury. Nejen oněm zhruba třiceti procentům lidí, kteří se dlouhodobě neúčastní „férových“ voleb, ale ani ostatním, nevidíme do hlavy. Přesto se s Matejem Cíbikem shodnu na konstatování, že naše soudobé panství je, ve weberiánském smyslu, legitimní. Lidé si stále ve své většině jsou ochotni osvojovat jazyk, jenž v různých oblastech života otevírá cestu $\mathrm{k}$ úspěchu na trhu práce, a dávají přednost konsensu - v tom, zda ,skutečnému“ či panujícím uspořádáním vynucenému, bychom se žrejmě

jednání v tou dobou nastupujícím neoliberálním pojetí uspořádání společnosti a hospodářského života: G. Becker, The Economic Approach to Human Behavior, Chicago 1976.

33 L. Hejdánek, Ideologie a kýč, in: Plamen, 6, 1968, str. 12-21, citováno podle: https://www.hejdanek.eu/File/Show/119 (navštíveno 23. června 2021). 
již rozcházeli - před otevřeným protestem či volbou těch politických subjektů, jež k takovému protestu vyzývají. Jeho legitimitu každodenně stvrzují svým jednáním. Nikoli ovšem nutně proto, že by v ni v nějakém autentickém smyslu ,veřrili““.

Zda lidé tváří v tvář drastickému prohlubování propastí mezi majetnými a nemajetnými či s povědomím o hrozící ekologické katastrofě, která bezprostředně souvisí s dynamikou kapitalistické exploatace, věří ve spravedlnost stávajícího systému a oprávněnost jeho elit k vládnutí, zkrátka nevíme. Stěží to proto bude moci být v budoucnu předmětem historického tázání. Co naopak studovat můžeme, jsou podoby osvojování si ideologie, z níž stávající systém vyrůstá, užívání povolených strategií jednání a reprodukce dominantních vzorců chování. Tedy to, co stávajícímu panství poskytuje potřebnou legitimitu v tom smyslu, jak s tímto pojmem v návaznosti na Maxe Webera pracují mimo jiné kulturní a sociální historici.

Jeden rozdíl oproti pozdnímu socialismu tu však přece jen je. Zatímco v osmdesátých letech byla myšlenka na emigraci ve smyslu opuštění daného společenského uspořádání živá, mnohými prakticky zvažovaná a, jak jsem vyložil výše, i v Československu praktikovaná - byt' byla spojená s řadou překážek a ne právě snadno realizovatelná -, v současnosti tuto alternativu, tzn. žít dále náš život moderního člověka mimo stávající kapitalistické vztahy, v praxi nemáme. Poslední ostrůvky s alternativními systémy jsou nejen většinou děsuplné, ale na celosvětově dominujícím kapitalistickém uspořádání společenských a ekonomických vztahů (nepřiznaně) stále závislejší. Kapitalismus, o jehož postupné přenesení na Mars a zřejmě i do dalších koutů vesmíru již někteří technologicky osvícení obchodníci se vší vážností hovoří, zkrátka zaživa opustit nelze. 